University of Nebraska - Lincoln

DigitalCommons@University of Nebraska - Lincoln

USDA National Wildlife Research Center - Staff

Publications

U.S. Department of Agriculture: Animal and Plant Health Inspection Service

May 1973

\title{
REPRODUCTION IN THE RED SQUIRREL (TAMIASCIURUS HUDSONICUS) IN COLORADO
}

Richard A. Dolbeer

Follow this and additional works at: https://digitalcommons.unl.edu/icwdm_usdanwrc

Part of the Environmental Sciences Commons

Dolbeer, Richard A., "REPRODUCTION IN THE RED SQUIRREL (TAMIASCIURUS HUDSONICUS) IN COLORADO" (1973). USDA National Wildlife Research Center - Staff Publications. 154.

https://digitalcommons.unl.edu/icwdm_usdanwrc/154

This Article is brought to you for free and open access by the U.S. Department of Agriculture: Animal and Plant Health Inspection Service at DigitalCommons@University of Nebraska - Lincoln. It has been accepted for inclusion in USDA National Wildlife Research Center - Staff Publications by an authorized administrator of DigitalCommons@University of Nebraska - Lincoln. 


\section{REPRODUCTION IN THE RED SQUIRREL (TAMIASCIURUS HUDSONICUS) IN COLORADO}

Information on reproduction of the red squirrel (Tamiasciurus hudsonicus) can be gleaned from studies in the northeastern United States (Klugh, 1927; Hamilton, 1939; Layne, 1954) and in western Canada (Miller, 1970; Smith, 1968; Kemp and Keith, 1971; Wood, 1967). However, there is a paucity of information on reproduction from the mountainous regions of the western United States. This paper presents reproductive information on the red squirrel from Colorado and helps fill this void. In addition, the reproductive strategy of red squirrels is briefly compared with that of snowshoe hares.

A total of 115 squirrels was collected by trapping between mid-April and September of 1970 and 1971 in Summit County, Colorado, 1 to 8 kilometers east of Vail Pass. Collections were made in coniferous forests of Englemann spruce (Picea englemanni), subalpine fir (Abies lasiocarpa) and lodgepole pine (Pinus contorta) at elevations of 3100 to 3400 
meters. Snowfall averages 630 centimeters annually and snow normally remains on the ground from October to early June.

Each squirrel was weighed and the general condition of teats or position of testes was noted. The whole reproductive tract of females and testes of males were removed and stored in 10 per cent formaldehyde. Subsequently, testes were weighed and measured and female reproductive tracts examined to determine their reproductive condition.

I used the following criteria to classify females as breeding or nonbreeding. Females collected in a definite state of estrus (long, coiled vagina with diameter $>7$ millimeterssee Layne, 1954, and Miller, 1970) were considered as breeding as were females containing visibly implanted fetuses. Females collected from June to September showing placental scars or longitudinal striations on the uterine wall also were considered as breeding (Kemp and Keith, 1971). All other females were considered as nonbreeding.

The condition of teats in July to September also was a useful criterion for determining breeding status. Females having nursed that year had conspicuous nipples ( $>3$ millimeters long), which contrasted with the inconspicuous nipples of nonbreeding females (Layne, 1954).

Each visible fetus was removed from the uterus and weighed. The average fetus weight was then obtained for each red squirrel litter. A fetal growth curve (based on weight) for snowshoe hares (Bookhout, 1964) was adjusted to estimate the approximate age of each red squirrel litter so that the approximate date of conception (fertilization of eggs) could be determined.

Red squirrels have a gestation period of about 40 days (Hamilton, 1939), which is similar to that of snowshoe hares ( 37 days). Snowshoe hares weigh 70 to 80 grams at birth whereas red squirrels weigh 7 to 8 grams (Svilha, 1930). Thus, the weight scale of the hare growth curve was reduced by a factor of 10 to estimate the age of red squirrel fetuses. Since fetal growth of altricial squirrels may not follow the exact pattern of fetal growth of precocial hares, the time of conception for each litter was estimated only to the nearest 10-day period of a month.

I considered squirrels 1 year or older as adults. No attempt was made to further age adults. Juvenile squirrels were first trapped in late August. The weight of juveniles collected in August and September (mean 125 grams, range 120 to 142) easily distinguished them from adults (mean weight 190 grams, range 151 to 250 ) in most cases. To assure that all juveniles were distinguished from adults, one humerus was removed from each squirrel collected in August and September. Juveniles were positively distinguished from adults by the presence or absence, respectively, of epiphyseal cartilage in the proximal end of the humerus, as described for the cottontail rabbit by Hale (1949).

The estimated period for conceptions (Fig. 1) in 1971 (mid-April through mid-May) was slightly earlier than in 1970 (May through mid-June). The time of appearance of lactating females also indicated earlier breeding in 1971 than in 1970. Two lactating females were collected on 1 June 1971, whereas in 1970 the first lactating female was not collected until 3 July.

The earlier breeding in 1971 than in 1970 may have been related to spring weather conditions. The snow depth in April and May was about 40 per cent less in 1971 than in 1970. Snowshoe hare breeding in the same locality also was earlier in 1971 than in 1970 (Dolbeer, 1972). Smith (1968) and Miller (1970) noted a similar relationship between snowfall and breeding chronology in red squirrel populations in British Columbia.

The period of conceptions in Colorado was generally later than that reported for red squirrels in localities at lower elevations farther north. Wood (1967) reported breeding in March and April in northen Alberta. Smith (1968) and Miller (1970) presented breeding records for 5 years in British Columbia. In different years, breeding first occurred in February, March, April, and early May. Layne (1954) and Hamilton (1939) recorded pregnancies in February and March in the northeastern United States. 


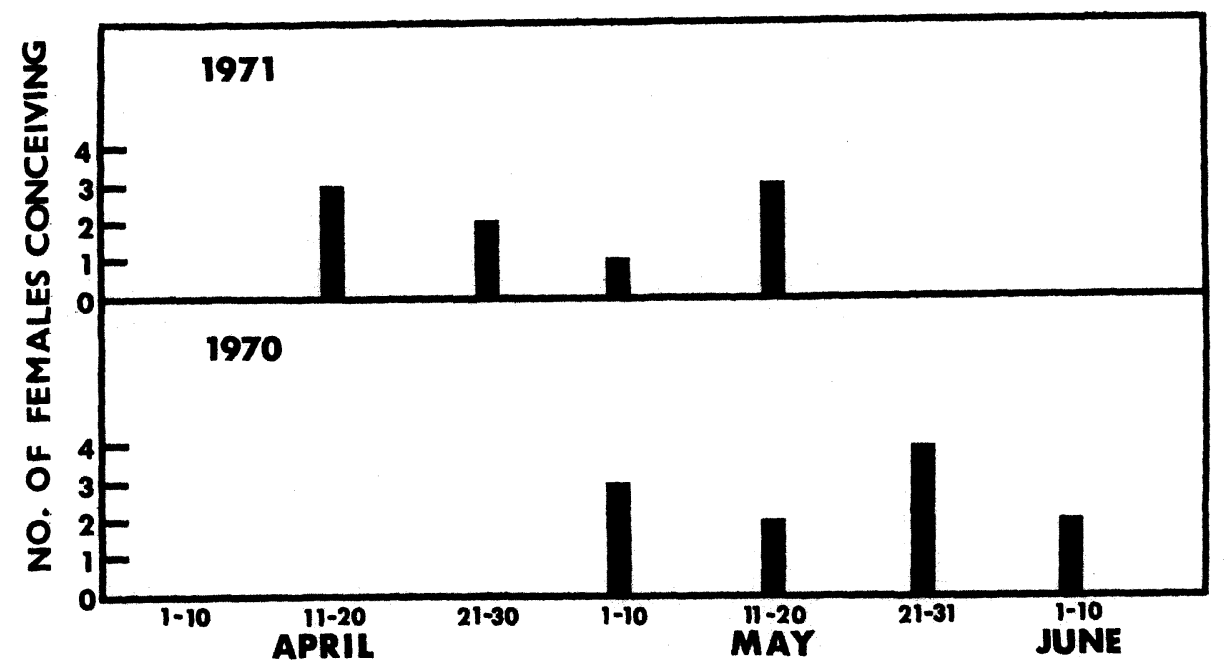

Fig. 1.-Estimated period of conceptions for red squirrels in Colorado, 1970-71.

I found no evidence of females producing two litters per year. The late initiation of breeding and short snow-free season virtually eliminated the possibility of a second litter in 1970 or 1971 . Inasmuch as red squirrels are not weaned until 2 months after birth (Nice et al., 1954), young born in 1970 and 1971 were not maternally independent until August or September.

Studies by Soper (1942), Hatt (1943), Smith (1968), and Kemp and Keith (1971) indicated that red squirrels produce only one litter per year in western North America. Miller (1970) did record the production of two litters in 1 of the 2 years of his study in British Columbia; however, an unusually mild spring occurred in that year and squirrels began breeding in February. In eastern United States, two litters per year are apparently common (Hamilton, 1939; Layne, 1954).

In my study the percentage of adult females breeding decreased significantly $(P<0.01$, Chi-square value $7.03,1 \mathrm{df})$ from 89 per cent $(N=27)$ in 1970 to 59 per cent $(N=39)$ in 1971. Significant annual variations in pregnancy rate are common for red squirrels in western North America. The percentage of adult females breeding increased from 67 per cent to 88 per cent over a 1-year period in Alberta (Kemp and Keith, 1971) and decreased from 83 per cent to 32 per cent over a 1-year period in British Columbia (Smith, 1968).

I found an average litter size (based on counts of visibly implanted fetuses) of 3.3 (range 2 to 5 , mode $3, N=16$ ) for 1970-71, which is similar to that reported for red squirrels in western Canada (Kemp and Keith, 1971; Smith, 1968). There was no significant difference in litter size between years $(P>0.20)$.

Layne (1954) found that testes in red squirrels weighing over 1 gram normally had viable spermatozoa in the cauda epididymis and that testes weighing less than 1 gram did not. Using Layne's (1954) criterion, the sexually functional period for adult males ended in early July in 1970 and in mid-June in 1971 in my study. The later functional period in 1970 than in 1971 corresponded with the later onset of breeding in 1970 than in 1971 (Fig. 1).

Snowshoe hares and red squirrels normally occur together in boreal coniferous forests of North America. Both are herbivores, remain above snow in winter, and are active yearround. Prebreeding population densities of more than 100 adults per square mile are common for both species (Meslow and Keith, 1968; Kemp and Keith, 1971). 
The annual reproductive rate of snowshoe hares is much higher than that of red squirrels. Snowshoe hares, throughout their geographic range, produce two to four litters annually. Average litter size ranges from two to three for first litters to three to five for later litters (Keith et al., 1966). The pregnancy rate is consistently high because more than 95 per cent of adult females surviving a breeding season normally produce at least two litters (Meslow and Keith, 1968; Newson, 1964; Dodds, 1965; Dolbeer, 1972).

On a long-term basis, red squirrel and snowshoe hare populations are remaining stable in areas where man has not removed their habitat. Therefore, red squirrels, on the average, maintain population numbers with a lower reproductive rate per female than do snowshoe hares. This indicates that the evolutionary strategy of these two sympatric species has been different. Snowshoe hares have evolved more as " $r$ strategists" (MacArthur and Wilson, 1967), maintaining a relatively high reproductive rate and the ability to rapidy increase in numbers under favorable conditions. Snowshoe hares have rather unspecialized food habits, they exhibit no overt defense of territory and populations apparently maintain little social structure (see Adams, 1959; Aldous, 1936; Bider, 1961). Populations have commonly undergone 15 to 100 fold fluctuations in density within 4 to 5 year periods (Keith, 1963: 135).

In contrast, red squirrels, with a lower reproductive rate, have evolved more as " $\mathrm{K}$ strategists." Red squirrels have specialized food habits, are highly territorial, and apparently have a rather complex social structure (Layne, 1954; Smith, 1968; Kemp and Keith, 1971). Population numbers do fluctuate on a short-term basis, apparently in relation to food supply (that is, cone crops-Kemp and Keith, 1971); however, annual density changes are not of the magnitude of those for snowshoe hares populations.

I thank Bruce A. Wunder for reading the manuscript and the Colorado Cooperative Wildlife Research Unit for financial assistance.

\section{Literature Cited}

Adams, L. 1959. An analysis of a population of snowshoe hares in northwestern Montana, Ecol. Monogr., 29:141-170.

Aldous, C. M. 1936. Food habits of Lepus americanus phaeonotus. J. Mamm., 17:175176.

Bider, J. R. 1961. An ecological study of the hare, Lepus americanus. Canadian J. Zool., 39:81-103.

Bookнout, T. A. 1964. Prenatal development of snowshoe hares. J. Wildlife Mgt., 28: 338-345.

Dopds, D. G. 1965. Reproduction and productivity of snowshoe hares in Newfoundland. J. Wildlife Mgt., 29:303-315.

Dolbeer, R. A. 1972. Population dynamics of the snowshoe hare in Colorado. Unpublished Ph.D. dissertation, Colorado State Univ., Ft. Collins, 189 pp.

HALE, J. B. 1949. Aging cottontail rabbits by bone growth. J. Wildlife Mgt., 13:216-225.

Hamilton, W. J., JR. 1939. Observations on the life history of the red squirrel in New York. Amer. Midland Nat., 22:732-745.

Hatt, R. T. 1943. The pine squirrel in Colorado. J. Mamm., 24:311-345.

Kerth, L. B. 1963. Wildlife's ten-year cycle. Univ. Wisconsin Press, Madison, xvi + $201 \mathrm{pp}$.

Keith, L. B., O. J. Rongstad, And E. C. Meslow. 1966. Regional differences in reproductive traits of the snowshoe hare. Canadian J. Zool., 44:953-961.

Kemp, G. A., AND L. B. Kerth. 1971. Dynamics and regulation of red squirrel (Tamiasciurus hudsonicus) populations. Ecology, 51:763-779.

KLUGH, A. B. 1927. Ecology of the red squirrel. J. Mamm., 8:1-32.

Layne, J. N. 1954. The biology of the red squirrel, Tamiasciurus hudsonicus loquax (Bangs), in central New York. Ecol. Monogr., 24:227-267. 
MacArthur, R. H., AND E. O. Wuson. 1967. The theory of island biogeography. Princeton Univ. Press, Princeton, New Jersey, 203 pp.

Meslow, E. C., AND L. B. KeIth. 1968. Demographic parameters of a snowshoe hare population. J. Wildlife Mgt., 32:812-834.

MrLler, J. S. 1970. The breeding season and reproductive cycle of the western red squirrel. Canadian J. Zool., 48:471-473.

Newson, J. 1964. Reproduction and prenatal mortality of snowshoe hares on Manitoulin Island, Ontario. Canadian J. Zool., 42:987-1005.

NiCE, M. M., C. NICE, AND D. EwERs. 1954. Comparison of behavior development in snowshoe hares and red squirrels. J. Mamm., 37:64-74.

SMIrH, C. C. 1968. The adaptive nature of social organization in the genus of tree squirrels Tamiasciumus. Ecol. Monogr., 38:31-63.

Soper, J. D. 1942. Mammals of Wood Buffalo Park, northern Alberta and District of MacKenzie. J. Mamm., 23:119-145.

SviLfa, R. D. 1930. Development of young red squirrels. J. Mamm., 11:79-80.

Woon, T. J. 1967. Ecology and population dynamics of the red squirrel (Tamiasciurus hudsonicus) in Wood Buffalo National Park. M.S. thesis, Univ. Saskatchewan, Saskatoon, 97 pp.

Richafo A. Dolbeen, U.S. Bureau of Sport Fisheries and Wildlife, P. O. Box 2097, Sandusky, Ohio 44870. Accepted 30 November 1972. 